\title{
PENGUKURAN KOGNITIF DAN USER EXPERIENCE APLIKASI LATIHAN MOTORIK HALUS PADA UMUR BERESIKO DEMENSIA
}

\author{
${ }^{1,2}$ Nova Eka Diana, ${ }^{1}$ Aprilianti Putri, ${ }^{1,2}$ Nurmaya, ${ }^{1,2}$ Elan Suherlan \\ ${ }^{1}$ Program Studi Teknik Informatika, Fakultas Teknologi Informasi, Universitas YARSI, Jakarta, Indonesia \\ ${ }^{2}$ YARSI E-Health Research Center (YEHRC) \\ E-mail: nova.diana@yarsi.ac.id
}

\begin{abstract}
This paper aims to measure the effectiveness of the web-based ping-pong exercise in improving respondent's cognitive level. User experience aspect is evaluated using User Experience Questionnaire (UEQ). The respondents in this research are 15 persons between 49 and 90 years old. Web-based Mini-Mental State Examination (MMSE) shows that our application improves the cognitive level of 66,67\% in average. UEQ experiment exhibits that our system is superior in term of attractiveness, perspicuity, dependability, and stimulation scale. However, the novelty scale is lower but still above average. The reason is the existence of the similar applications with different type of cognitive exercises.
\end{abstract}

Keywords: cognitive, user experience questionnaire, mini-mental state examination

\begin{abstract}
Abstrak
Paper ini menjelaskan tentang rancang bangun aplikasi berbasis web sebagai media latihan motorik bagi umur beresiko demensia. Tujuan dari paper ini adalah mengukur efektivitas aplikasi dalam mengukur kognitif responden serta nilai user experience aplikasi terhadap pengguna. Jenis latihan motorik yang dikembangkan dalam aplikasi ini adalah permainan ping-pong dengan dua mode yaitu pemain tunggal dan pemain ganda. 15 orang responden dengan rentang umur 45-90 tahun diminta untuk menggunakan aplikasi selama 5-10 menit sebanyak tiga kali, dengan jeda antar percobaan adalah satu hari. Hasil tes Mini-Mental State Examination (MMSE) sebelum dan sesudah perlakuan menunjukkan peningkatan kognitif pengguna dengan rata-rata $66,67 \%$. Hasil UEQ menunjukkan keunggulan aplikasi pada skala: daya tarik, kejelasan, efisiensi, ketepatan, dan stimulasi. Sedangkan nilai kebaruan dari aplikasi adalah di atas rata-rata dikarenakan telah adanya aplikasi-aplikasi dengan sifat yang hampir sama, yaitu melatih sisi kognitif pengguna namun dengan jenis latihan yang berbeda.
\end{abstract}

Kata Kunci: kognitiv, user experience questionnaire, mini-mental state examination

\section{Pendahuluan}

Demensia adalah sindrom klinis yang meliputi penurunan kemajuan fungsi intelektual. Beberapa kemampuan kognitif yang dipengaruhi oleh demensia antara lain ingatan, bahasa, berpikir secara logis, mengambil keputusan, fungsi visuos-spasial, perhatian, dan orientasi. Biasanya gangguan fungsi kognitif ini menyebabkan terjadinya perubahan kepribadian, pengaturan emosi, serta perilaku sosial. Akibatnya, perubahan-perubahan tersebut dapat mengganggu aktivitas harian serta hubungan dengan orang-orang sekitar (Korolev 2012).

Kondisi demensia dapat disebabkan oleh beberapa penyakit, antara lain Alzheimer, vaskular, Parkinson, lewy body, dan frontotemporal demensia. Alzheimer adalah penyakit gangguan degenerative otak yang bersifat kronik dan progresif. Ditemukan pertama kali oleh Alois Alzheiemer pada tahun 1906, Alzheimer adalah penyebab paling umum terjadinya penyakit demensia dengan jumlah kasus sebesar $60 \%$ sampai dengan $80 \%$ (Alzheimer's Association n.d.).

Pada umumnya, demensia terjadi pada orang 
berusia diatas 65 tahun. Namun, penyakit ini dapat juga menghampiri lebih awal yaitu pada usia 40 atau 50 tahun (Alzheimer's Association n.d.).

Alzheimer's Disease Indonesia (ADI) memperkirakan terdapat 46,8 juta penderita demensi di seluruh dunia. Pada 20 tahun mendatang, nilai ini diperkirakan meningkat menjadi dua kali lipat menjadi 74,7 di tahun 2030 dan 131,5 juta di tahun 2050. Asia memiliki kasus demensia terbanyak sebesar $49 \%$ dari seluruh kasus di dunia. Biaya yang dihabiskan dalam penanganan penderita demensia sebesar 818 milyar US Dollar (USD) di tahun 2015. Biaya ini termasuk biaya penanganan secara informal, sosial, dan medis. Biaya medis menghabiskan $20 \%$ dari seluruh biaya penanganan, sedangkan biaya penanganan secara informal dan sosial masing-masing sebesar $40 \%$.

Untuk mencegah peningkatan jumlah penderita demensia yang berakibat pada meningkatnya biaya pengobatan, diperlukan penanganan secara dini untuk mencegah dan mengelola proses penyembuhan penderita demensia. Studi yang dilakukan oleh Ontario Brain Institute (2013) menyebutkan bahwa aktivitas fisik memiliki potensi untuk mencegah dan mengelola penyembuhan penyakit demensia di Ontario. Pemberian aktivitas fisik secara teratur pada penderita demensia Alzheimer yang berusia lanjut, menunjukkan bahwa aktivitas fisik dapat meningkatkan kualitas hidup (quality of life), aktivitas keseharian (activities of daily living), serta menurunkan tingkat depresi para penderita (Ontario Brain Institute 2013).

Penelitian ini bertujuan untuk mengukur peningkatan kognitif orang yang memiliki umur teresiko demensia, setelah melakukan aktivitas fisik yaitu memainkan sebuah permainan pingpong berbasis web. Pengukuran dilakukan dengan menggunakan MMSE (Mini Mental State Examination). Pengujian user experience juga dilakukan terhadap aplikasi permainan.

\section{Metodologi}

\subsection{Rancangan Penelitian}

Penelitian ini menggunakan rancangan penelitian eksperimen yaitu One-Group PretestPosttest Design. Dalam rancangan ini, pengujian awal (Pretest) dilakukan pada sebuah kelompok sebelum diberikan perlakuan, yang kemudian dilakukan pengujian kembali (Posttest) setelah perlakuan selesai diberikan. Tujuan dari rancangan penelitian ini adalah untuk melihat keefektifan dari perlakuan yang diberikan kepada partisipan. Tabel 1 menunjukkan desain penelitian One-Group Pretest-Posttest Design.

Tabel 1. Rancangan Penelitian One-Group Pretest-Posttest Design (Sugiyono, 2008)

\begin{tabular}{ccc}
\hline Pretest & Treatment & Posttest \\
\hline $\mathrm{O}_{1}$ & $\mathrm{X}$ & $\mathrm{O}_{2}$ \\
\hline
\end{tabular}

\subsection{Mini-Mental State Examination (MMSE)}

Beberapa alat telah dikembangkan untuk mengevaluasi kemampuan kognitif, keseimbangan, serta kemampuan fungsional para lansia, yaitu antara lain: Mini-Mental State Examination (MMSE), Timed Up and Go Test (TUG), Step Test, FRT, Index Bartel, dan LateLife and Disability Instrument (LLFDI) (Takarini, Wahyono \& Utomo 2012). Diantara alat tersebut, MMSE adalah alat yang secara klinis paling lengkap dalam mengukur kemampuan kognitif dan status mental pada usia lanjut (Kochhann, Cerveira, Godinho, Camozzato \& Chaves 2009).

Pemeriksaan kognitif dengan alat evaluasi MMSE biasanya dilakukan dengan durasi 5-10 menit. Pada pemeriksaan ini diberikan 11 pertanyaan yang dapat menilai kinerja fungsi lima daerah kognitif, yaitu, orientation, registration, attention and calculation, recall, dan language. Setiap pertanyaan memiliki bobot nilai yang berbeda dengan total nilai MMSE adalah 30 . Pemetaan nilai MMSE terhadap kondisi penderita Demensia Alzheimer dapat dilihat pada Tabel 2. Terdapat 4 kategori penderita demensia Alzheimer berdasarkan nilai MMSE yaitu normal, ringan, sedang, dan parah. Penderita dengan kategori kognitif normal masih dapat melakukan aktivitas sehari-hari seperti layaknya orang normal yang lain. Sedangkan kategori parah selalu memerlukan bantuan dari orang sekitarnya untuk dapat melakukan aktivitas sehari-hari.

Tabel 2. Tingkatan Alzheimer berdasarkan MMSE

\begin{tabular}{|c|c|}
\hline Nilai MMSE & Kemampuan Otonomi \\
\hline $0-9$ & Ketergantungan total \\
\hline $10-17$ & Butuh pengawasan \\
\hline $18-26$ & Tidak tergantung pada orang lain \\
\hline $27-30$ & Tidak bermasalah \\
\hline $\begin{array}{l}\text { Pad } \\
\text { diberikar } \\
27 \text { pertar } \\
\text { total nila } \\
\text { dapat } \\
\text { memperl } \\
\text { area kog }\end{array}$ & $\begin{array}{l}\text { penelitian ini, tes MMSE yang } \\
\text { epada responden adalah sebanyak total } \\
\text { aan untuk semua area kognitif dengan } \\
\text { 0. Bobot nilai dari setiap area kognitif } \\
\text { ihat pada Gambar } 1 . \text { Tabel } 3 \\
\text { atkan daftar pertanyaan untuk setiap } \\
\text { if, yaitu } 10 \text { pertanyaan untuk orientasi }\end{array}$ \\
\hline
\end{tabular}


dengan masing-masing bernilai 1,3 pertanyaan registrasi yang bernilai 1 untuk setiap itemnya, 5 pertanyaan untuk attention and calculation, 3 pertanyaan untuk recall, dan 6 buah pertanyaan untuk area bahasa dengan variasi nilai dari 1 sampai dengan 3 .

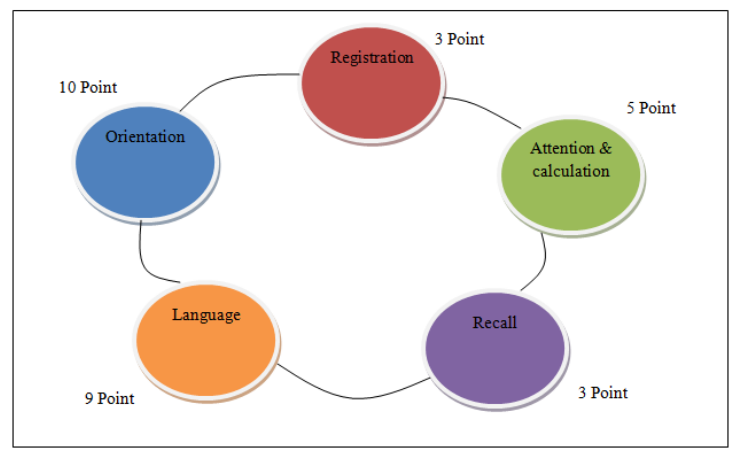

Gambar 1. Hasil Uji Normalisasi

Tabel 3. Daftar pertanyaan MMSE

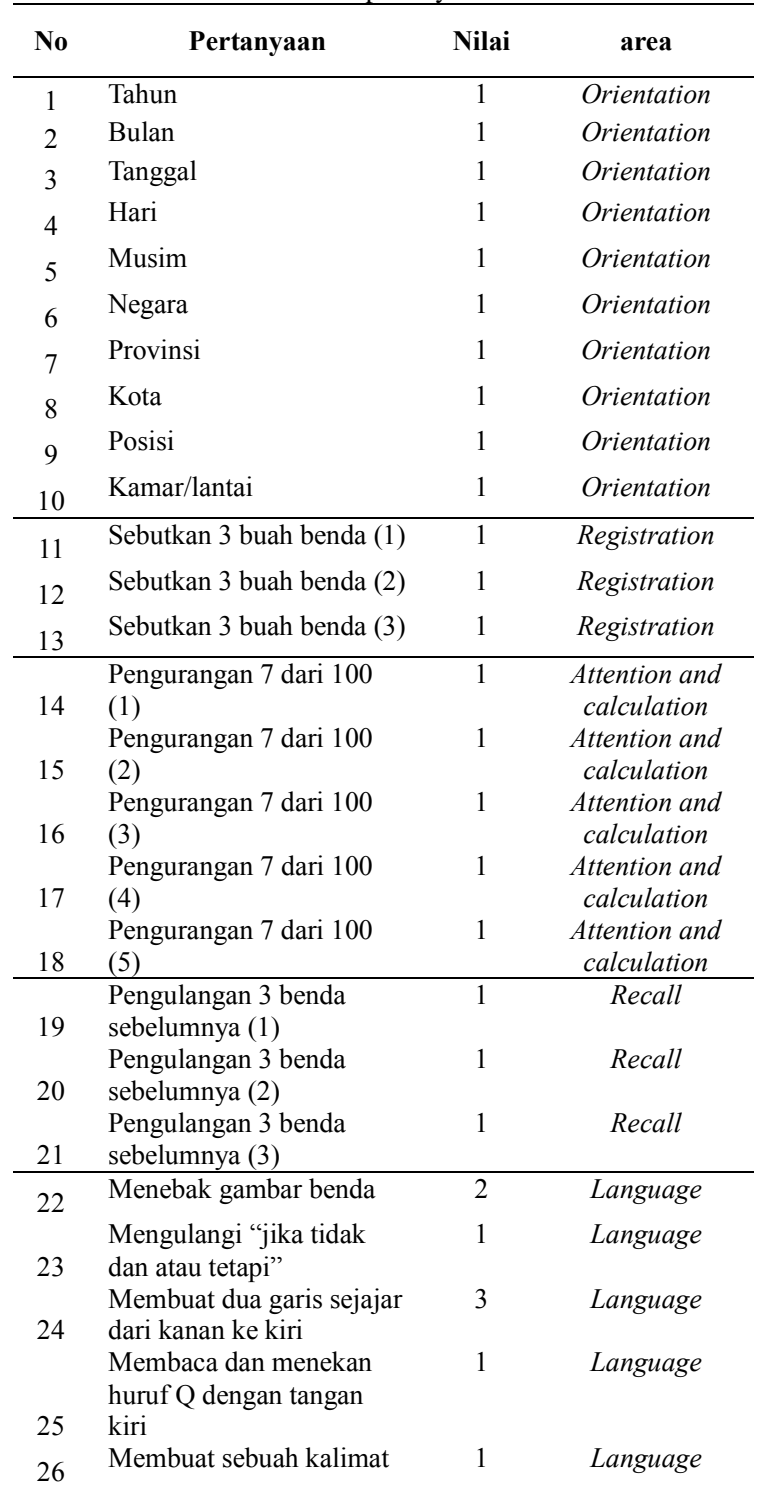

27

Menirukan gambar

$1 \quad$ Language

\subsection{User Experience Questionnaire (UEQ)}

User Experience Questionnaire (UEQ) biasanya digunakan untuk mengukur evaluasi experience pengguna terhadap aplikasi. Ada enam skala penting yang diukur oleh UEQ yaitu daya tarik, kejelasan, efisiensi, ketepatan, stimulasi dan kebaruan. Tiap skala tersebut dinyatakan dalam item-item kuisioner dengan jumlah keseluruhan sebanyak 26. Kuisioner terlihat pada Gambar 2.

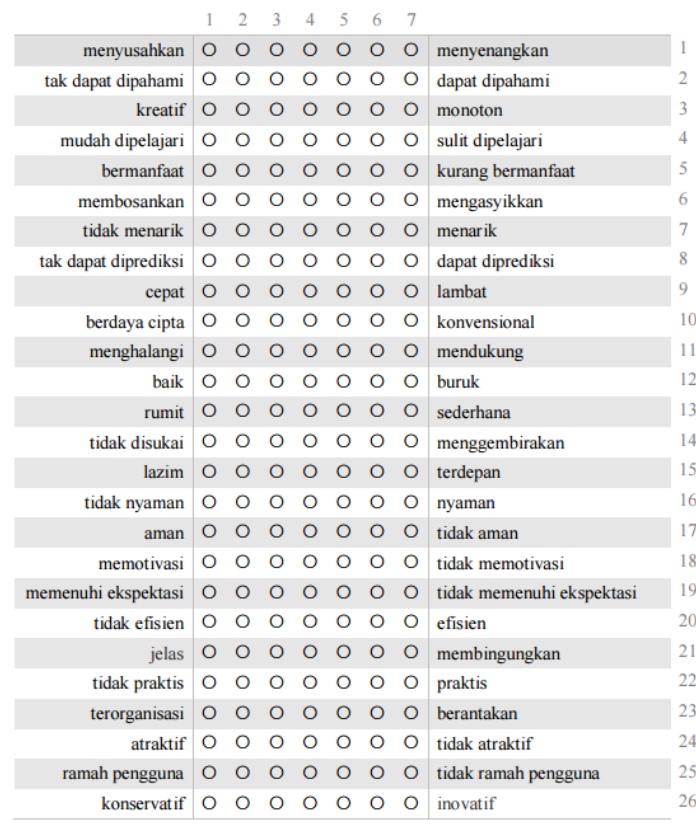

Gambar 2. Alat evaluasi UEQ (Diana \& Saputra 2015)

\subsection{Desain dan Arsitektur Aplikasi}

Gambar 3 memperlihatkan arsitektur dari aplikasi yang dibangun pada penelitian ini. Aplikasi yang dibangun terdiri dari 3 tingkatan, yaitu presentation layer, business layer, dan data access layer. Presentation layer adalah lapisan yang terdiri atas fitur-fitur yang dapat diakses secara langsung oleh pengguna, meliputi: MMSE Quiz, Ping-Pong Game, Ping-Pong Score, MMSE Score, dan Activity History. Data yang dimasukkan oleh pengguna pada lapisan ini akan disimpan oleh business layer dan kemudian dikomunikasin ke data access layer. Data access layer bertugas untuk menyimpan dan mengakses data ke dan dari basis data.

Aplikasi yang dibangun dirancang untuk dapat digunakan oleh tiga jenis pengguna yaitu, patient, caregiver, dan admin. Patient adalah pengguna dengan rentang usia 45-90 tahun yang beresiko memiliki penyakit demensia. Caregiver adalah orang-orang yang berada di sekitar 
penderita demensia yang bertugas untuk membantu keseharian aktivitas penderita, meliputi perawat dan kerabat dekat pasien. Admin disini bertugas untuk mengelola semua data pengguna, baik patient maupun caregiver. Jenis fungsi yang dapat dilakukan oleh setiap pengguna dapat dilihat pada daftar use case pada Gambar 4. Desain basis data dari aplikasi yang dibangun dapat dilihat pada Gambar 5. Terdapat 6 buah tabel penting yang berhasil diidentifikasi untuk membangun aplikasi dalam penelitian ini, yaitu: Pasien, Game, Caregiver, Game Progress Score, MMSE Progress, dan MMSE.

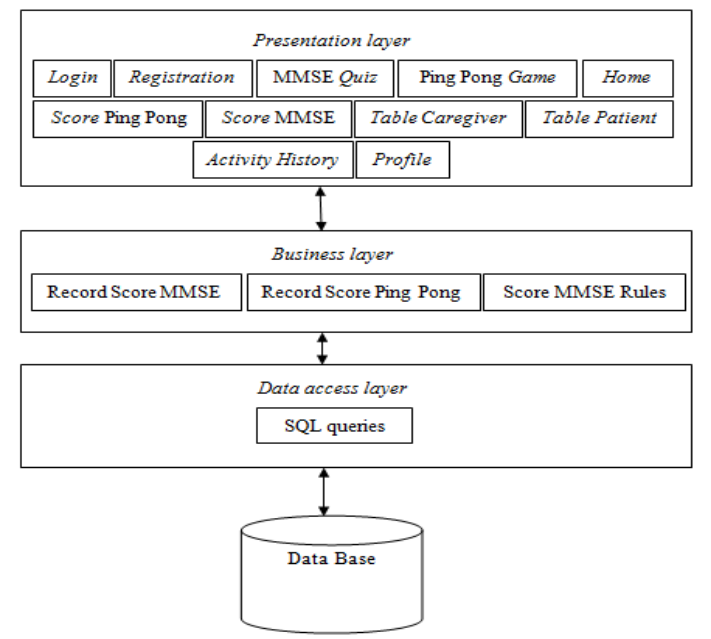

Gambar 3. Arsitektur aplikasi

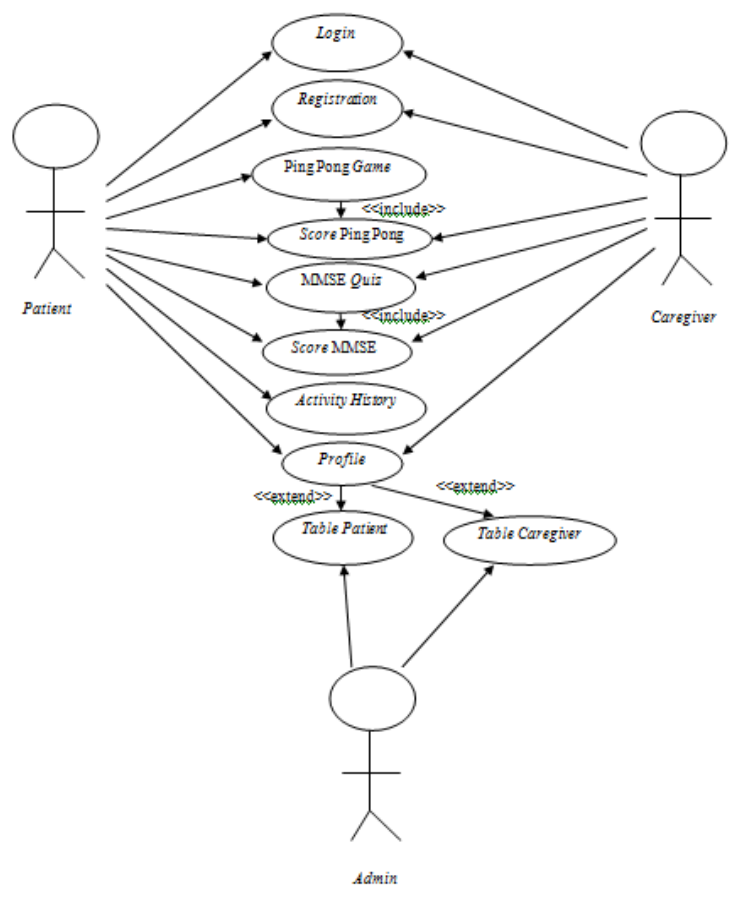

Gambar 4. Use Case Diagram

\section{Hasil dan Pembahasan}

\subsection{Pemilihan Responden}

Sebanyak 15 responden dengan profesi sebagai ibu rumah tangga, dosen, guru, karyawan, wirausaha, pensiunan dan tidak bekerja dipilih sebagai objek penelitian. Responden dalam penelitian ini dipilih dengan kriteria berumur 45 sampai 90 tahun, dimana seseorang dalam rentang usia 45 tahun ke atas memiliki potensi terkena Demensia Alzheimer.

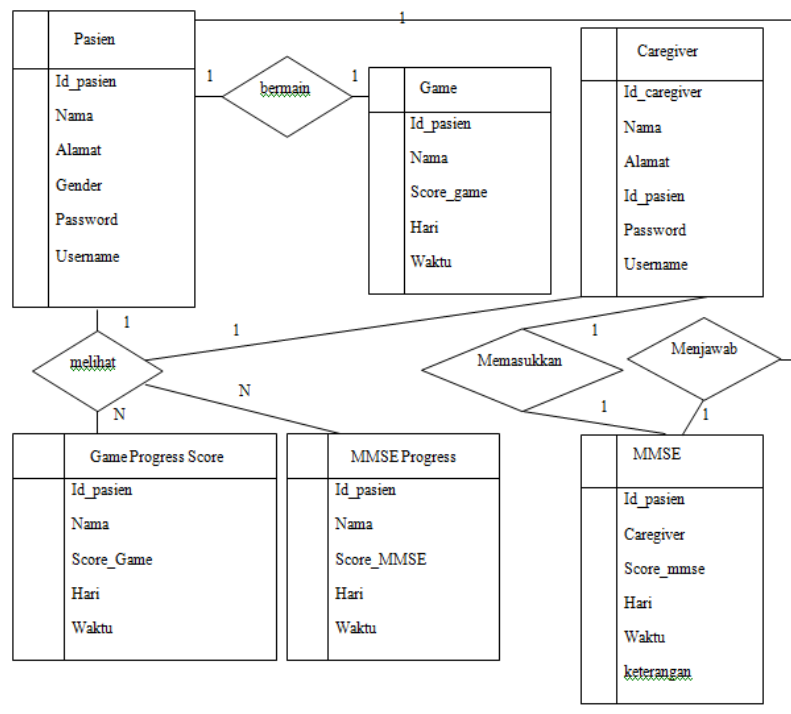

Gambar 5. Desain ERD

Skenario pengujian yang diberikan kepada responden dibagi ke dalam tiga kali pertemuan, dengan jeda untuk setiap pertemuan adalah sebanyak satu hari. Detail dari skenario pengujian yang diberikan adalah sebagai berikut;

- Pertemuan 1 :

Responden diberikan tes MMSE untuk mengukur nilai kognitif sebelum diberikan perlakuan. Selanjutnya, responden diminta untuk memainkan permainan ping-pong secara online yang disediakan oleh aplikasi. Responden diberikan tiga kali kesempatan untuk mencoba permainan ini. Nilai permainan ping-pong pada setiap kesempatan serta nilai MMSE dari responden akan disimpan oleh aplikasi sebagai sumber untuk melihat kemajuan kemampuan kognitif responden.

- Pertemuan 2 :

Pada pertemuan kedua, responden diberikan perlakuan bermain ping-pong sebanyak 1-3 kali kesempatan. Seperti halnya dengan pertemuan pertama, responden memainkan 
permainan ini dengan rentang waktu rata-rata 2-5 menit.

- Pertemuan 3 :

Pada pertemuan terakhir ini, responden diberikan perlakuan yang sama dengan pertemuan kedua. Setelah itu, responden diminta untuk melakukan tes MMSE kembali. Nilai MMSE pada pertemuan ini akan dibandingkan dengan nilai yang diperoleh pada pertemuan ini.

Item pertanyaan MMSE yang diberikan sebelum dan sesudah perlakuan adalah sama persis. Jumlah pertanyaan adalah sebanyak 27 item yang dapat dikelompokkan menjadi orientation, registration, attention and calculation, recall, dan language. Tingkat kesulitan yang diberikan sebelum dan sesudah perlakuan juga sama. Hal ini bertujuan untuk melihat efektivitas aplikasi yang dibangun terhadap peningkatan nilai kognitif responden. Daftar pertanyaan yang diberikan kepada responden dapat dilihat pada Tabel 3 seperti disebutkan pada sub bab 2.2.

\subsection{Pengukuran MMSE}

Tabel 4 memperlihatkan daftar nilai MMSE dari responden sebelum dan sesudah perlakuan, yaitu berlatih permainan ping-pong secara online. Sebelum diberikan perlakuan, uji MMSE menunjukkan bahwa nilai kognitif dari enam responden diidentifikasi sebagai normal dan sembilan responden diidentifikasi menderita demensia ringan.
Hasil pemberian perlakuan latihan motorik berupa permainan ping-pong secara online, menunjukkan bahwa sebanyak 10 responden mengalami peningkatan kemampuan kognitif dengan rata-rata peningkatan nilai MMSE adalah 3,4 poin. Akan tetapi, terdapat dua orang responden yang mengalami penurunan kemampuan kognitif dengan nilai MMSE berkurang sebanyak 1-2 poin. Penurunan nilai ini disebabkan oleh kurangnya konsentrasi dan terbaginya perhatian terhadap pekerjaan yang lain ketika diminta untuk melakukan kuis MMSE.

Pengaruh pemberian perlakuan permainan ping-pong secara online terhadap kelima area kognitif responden dapat dilihat pada Gambar 6 . Nilai dari keseluruhan item pertanyaan pada alat ukur MMSE telah dinormalisasi ke dalam rentang $[-1,1]$. Nilai 1 menyatakan bahwa responden mengalami peningkatan pada item tersebut, 0 menyatakan tidak ada perubahan, dan -1 menyatakan bahwa responden mengalami penurunan dalam menjawab item pertanyaan setelah diberikan perlakuan.

Rangkuman keseluruhan dari hasil normalisasi terhadap lima area kognitif dapat dilihat pada Gambar 7. Terlihat bahwa pemberian perlakuan dapat meningkatkan kemampuan kognitif pada area orientation, attention and calculation, recall, dan language dengan probabilitas peningkatan sebesar 0,4 sampai dengan 0,67. Dari keseluruhan area kognitif, attention and calculation adalah area yang perlu mendapatkan penanganan secara khusus karena $60 \%$ responden mengalami penurunan kognitif pada area tersebut setelah diberikan perlakuan.

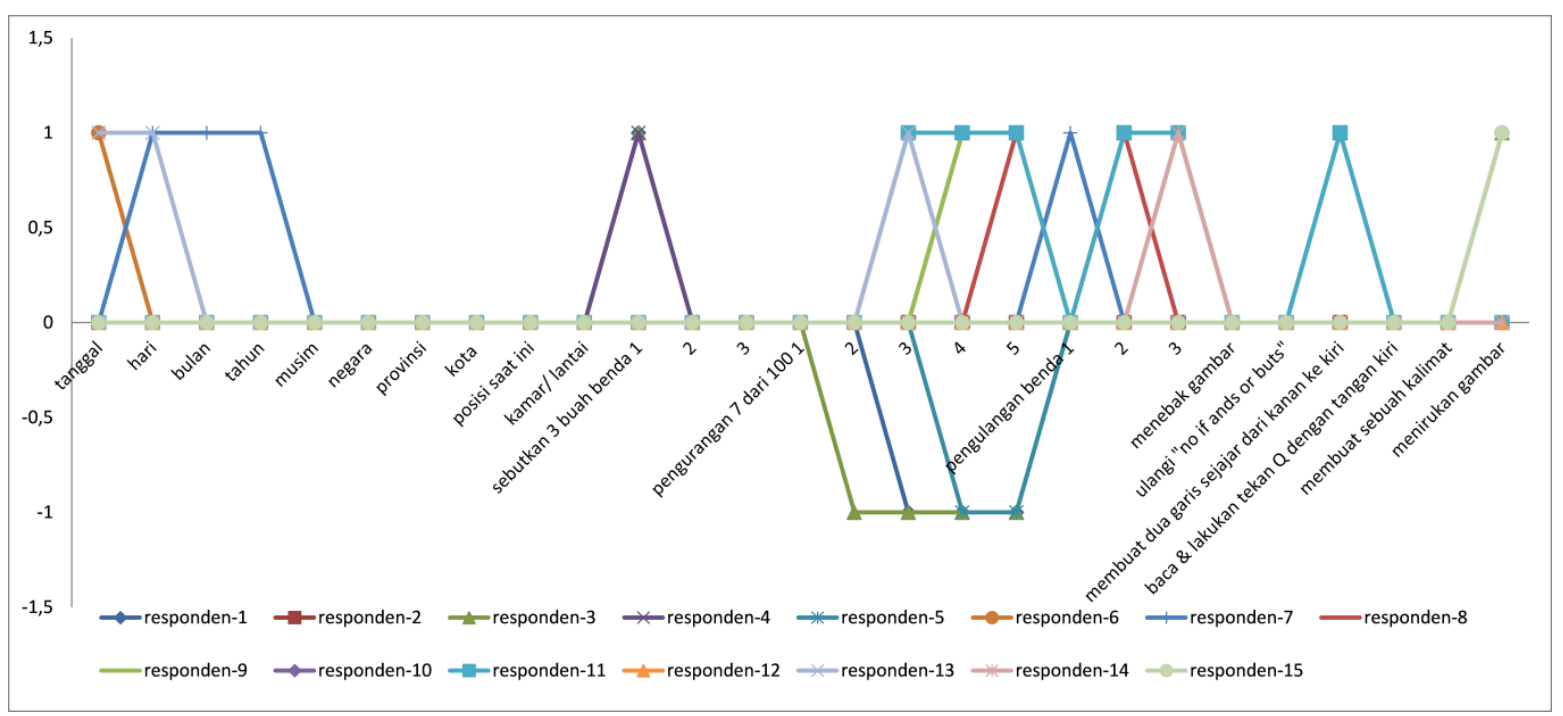

Gambar 6. Normalisasi perkembangan area kognitif responden 


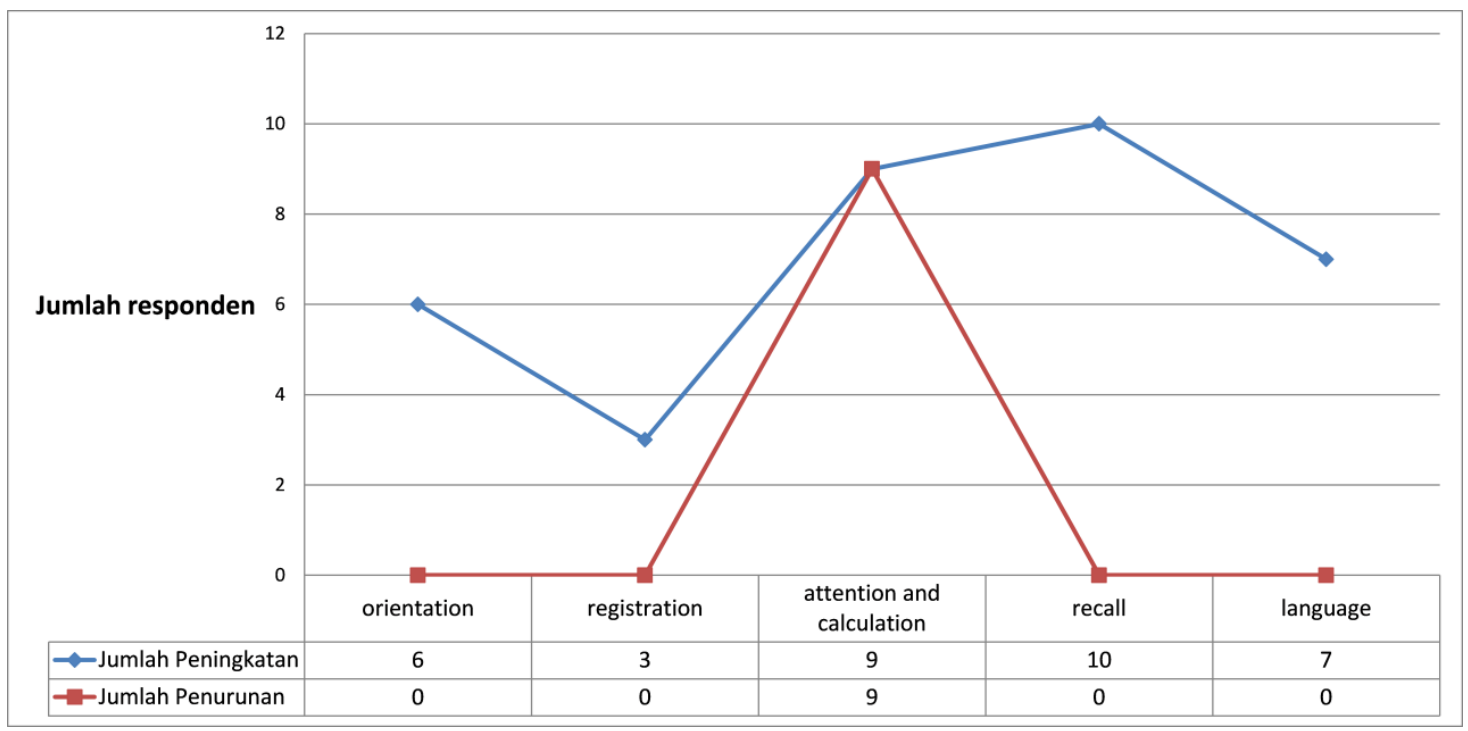

Gambar 7. Rangkuman pengaruh permainan ping-pong terhadap area kognitif

Secara keseluruhan, pemberian latihan motorik berupa permainan ping-pong online mampu meningkatkan nilai kognitif responden dengan presentase sebesar 66,67\%. Namun dengan peningkatan nilai MMSE yang tidak terlalu tinggi. Faktor yang berpengaruh terhadap peningkatan nilai kognitif tersebut meliputi waktu pengujian, keadaan lingkungan, serta kondisi pikiran responden selama diberikan perlakuan. Semakin tinggi frekuensi pemberian perlakuan dengan kondisi lingkungan dan fikiran yang tenang, probabilitas perbaikan kondisi kognitif responden juga semakin meningkat.

Tabel 4. Nilai MMSE hasil pengujian

\begin{tabular}{ccclcl}
\multicolumn{5}{c}{ Tabel 4. Nilai MMSE hasil pengujian } \\
\hline & & \multicolumn{2}{c}{$\begin{array}{c}\text { MMSE } \\
\text { (sebelum) }\end{array}$} & $\begin{array}{c}\text { MMSE } \\
\text { (sesudah) }\end{array}$ \\
\cline { 3 - 6 } No & Usia & Nilai & Kategori & Nilai & Kategori \\
& & & & & \\
& & & & & \\
\hline 1 & 46 & 28 & Normal & 27 & Normal \\
2 & 53 & 30 & Normal & 30 & Normal \\
3 & 60 & 28 & Normal & 26 & Ringan \\
4 & 63 & 25 & Ringan & 29 & Normal \\
5 & 53 & 24 & Ringan & 27 & Normal \\
6 & 58 & 24 & Ringan & 29 & Normal \\
7 & 81 & 20 & Ringan & 24 & Ringan \\
8 & 66 & 26 & Ringan & 28 & Normal \\
9 & 50 & 26 & Ringan & 30 & Normal \\
10 & 68 & 28 & Normal & 28 & Normal \\
11 & 61 & 21 & Ringan & 29 & Normal \\
12 & 49 & 28 & Normal & 28 & Normal \\
13 & 45 & 22 & Ringan & 25 & Ringan \\
14 & 90 & 21 & Ringan & 22 & Ringan \\
15 & 57 & 29 & normal & 30 & Normal \\
\hline & & & & &
\end{tabular}

\subsection{Pengukuran UEQ}

Tabel 5 dan Gambar 8 mengilustrasikan hasil pengukuran user experience pengguna terhadap sistem dengan menggunakan UEQ. Terdapat 6 skala yang diujikan yaitu daya tarik, kejelasan, efisiensi, ketepatan, stimulasi, dan kebaruan. Hasil pengujian menunjukkan bahwa sistem yang dibangun memiliki nilai yang sangat bagus (nilai mean diatas 2) pada skala daya tarik, efisiensi dan ketepatan. Nilai dari kejelasan dan stimulasi juga masih bagus yaitu antara 1,70 2,00. Perolehan nilai mean diatas 1,5 menunjukkan bahwa sistem yang dibangun mampu menarik dan menstimulasi pengguna untuk kembali menggunakan sistem ini pada kesempatan dan waktu yang lain. Sistem memiliki konsep, tujuan dan cara pemakaian yang sangat jelas dan mudah dipahami oleh pengguna. Keberadaan faktor-faktor tersebut membantu pengguna untuk menyelesaikan tugas yang diberikan dengan tepat dan efisien.

Hasil dari pengujian menggunakan UEQ, seperti terlihat pada Gambar 9, memberikan nilai tinggi pada semua skala kecuali kebaruan yang hanya memperoleh nilai mean sebesar 1,050 . Pemetaan untuk semua skala hasil pengujian terhadap nilai benchmark juga menunjukkan bahwa sistem yang dibangun berada pada posisi di atas rata-rata dibandingkan dengan sistem lainnya. Lima buah skala berada dalam kategori "excellent" dan satu skala kebaruan di kelompok "good".

Nilai kebaruan mendapat nilai terendah, karena di pasaran sudah ada aplikasi dengan tujuan yang hampir mirip (misalnya Lumosity) dengan aplikasi yang dibangun pada penelitian 
ini. Hal yang membedakan antara sistem yang dibangun dengan aplikasi-aplikasi yang sudah ada adalah terletak pada jenis permainan yang dibangun. Pada penelitian ini, jenis permainan yang disediakan bertujuan untuk melatih motorik halus dari pengguna. Selain itu, sistem ini juga dilengkapi dengan evaluasi level kognisi yang diberikan secara online sehingga hasilnya dapat langsung diketahui dan terekam di dalam basis data.

Tabel 5. Hasil perhitungan UEQ

\begin{tabular}{|l|c|c|c|c|c|c|}
\hline \multicolumn{7}{|c|}{ Confidence intervals $(\mathbf{p}=\mathbf{0 . 0 5})$ per scale } \\
\hline Scale & Mean & $\begin{array}{c}\text { Std. } \\
\text { Dev. }\end{array}$ & $\mathbf{N}$ & $\begin{array}{c}\text { Confi } \\
\text { dence }\end{array}$ & \multicolumn{2}{|c|}{$\begin{array}{c}\text { Confidence } \\
\text { interval }\end{array}$} \\
\hline $\begin{array}{l}\text { Daya } \\
\text { tarik }\end{array}$ & 2,256 & 0,884 & 15 & 0,447 & 1,808 & 2,703 \\
\hline $\begin{array}{l}\text { Kejela } \\
\text { san }\end{array}$ & 1,867 & 1,224 & 15 & 0,620 & 1,247 & 2,486 \\
\hline $\begin{array}{l}\text { Efisie } \\
\text { nsi }\end{array}$ & 2,267 & 0,753 & 15 & 0,381 & 1,886 & 2,648 \\
\hline $\begin{array}{l}\text { Ketep } \\
\text { atan }\end{array}$ & 2,033 & 0,901 & 15 & 0,456 & 1,578 & 2,489 \\
\hline $\begin{array}{l}\text { Stimul } \\
\text { asi }\end{array}$ & 1,967 & 1,285 & 15 & 0,650 & 1,317 & 2,617 \\
\hline $\begin{array}{l}\text { Kebar } \\
\text { uan }\end{array}$ & 1,050 & 1,057 & 15 & 0,535 & 0,515 & 1,585 \\
\hline
\end{tabular}
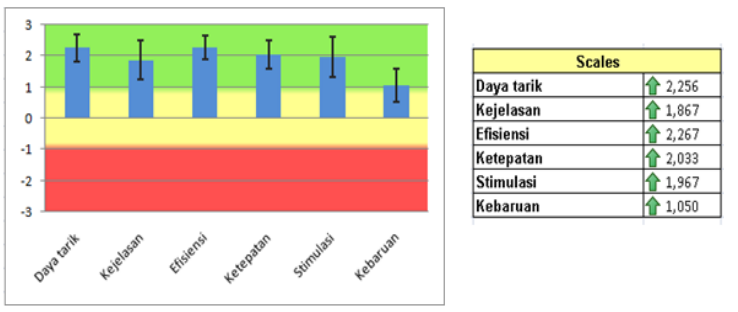

Gambar 8. Hasil UEQ

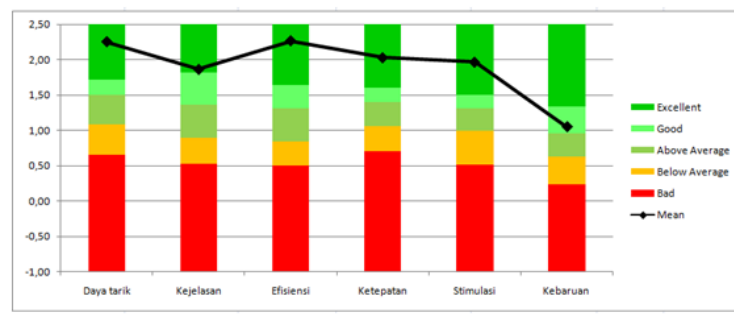

Gambar 9. Hasil UEQ terhadap benchmark

\section{Kesimpulan}

Artikel ini menjelaskan tentang rancang bangun sistem berbasis web yang dilengkapi dengan fitur latihan motorik berupa permainan ping-pong serta evaluasi kondisi kognitif (MMSE) secara online. Pengujian terhadap sistem dibagi menjadi dua yaitu efektivitas latihan motorik yang disediakan terhadap kemampuan kognitif serta sisi experience aplikasi terhadap pengguna. Uji efektivitas menunjukkan bahwa sistem mampu meningkatkan kemampuan kognitif pengguna dengan presentase $66,67 \%$, meskipun dengan kenaikan nilai MMSE yang tidak terlalu tinggi. Pengujian menggunakan alat UEQ menunjukkan bahwa sistem yang dibangun memiliki keunggulan pada skala daya tarik, kejelasan, efisiensi, ketepatan, dan stimulasi. Meskipun skala kebaruan bernilai rendah dibandingkan kelima skala yang lain, namun kebaruan dari aplikasi masih berada pada posisi di atas rata-rata sesuai dengan benchmark standar dari UEQ.

Penambahan jenis latihan motorik perlu ditambahkan untuk melatih aspek motorik halus dan kasar dari pengguna dengan usia beresiko demensia. Penambahan frekuensi pemberian perlakuan latihan motorik serta jarak evaluasi nilai MMSE yang jauh perlu dilakukan untuk lebih melihat dampak dan efektivitas dari latihan motorik secara online terhadap kemampuan kognitif pengguna.

\section{Acknowledgement}

Ucapan terima kasih disampaikan kepada Universitas YARSI yang telah membiayai penelitian ini melalui pemberian dana dengan skema Hibah Internal.

\section{Referensi}

Alzheimer's Disease Internasional n.d., Dementia statistics, ADI, viewed 26 Agustus 2016, https://www.alz.co.uk/research/statistics.

Alzheimer's Association n.d., What Is Alzheimer's ?,viewed 26 Agustus 2016, http://www.alz.org/alzheimers_disease_what_i s_alzheimers.asp.

Diana, N.E. \& Saputra, O. D. 2015, 'Measuring user experience of a potential shipment tracking application', Proceedings of The International $\mathrm{HCI}$ and $U X$ Conference in Indonesia, pp. 47-51.

Kochhann, R., Cerveira, M.O. , Godinho, C., Camozzato, A. \& Chaves, M., L., F. 2009, 'Evaluation of Mini-mental State Examination scores according to different age and education strata, and sex, in a large Brazilian healty sample', Dementia \& Neuropsychological, vol. 3, no. 2, pp.88-93.

Korolev, I.O. 2014, 'Alzheimer's disease: a clinical and basic science review', Medical Student Research Journal, vol. 4, Fall Issue, pp.24-33.

Ontario Brain Institute 2013, The role of physical activity in the prevention and management of alzheimer's disease-implications for ontario, USA:Ontario Brain Institute, viewed 26 
Agustus

2016 , www.braininstitute.ca/sites/default/files/final_r eport_obi_pa_alzheimers_february_25_2013.p df.

Sugiyono 2008, Metode Penelitian Kuantitatif Kualitatif dan $R \& D$, Alfabeta, Bandung.
Takarini, N., Wahyono, Y. \& Utomo, B. 2012, 'Alat ukur sederhana untuk evaluasi kognitif keseimbangan dan aktivitas fungsional lansia', Jurnal Terpadu Ilmu Kesehatan, vol. 1, no. 1, pp.54-60. 